\title{
Studying the impact of market factors in planning of promotional campaigns for the offices of the Ministry of Tourism abroad
}

\author{
Hany Ahmed Aly Khattab \\ Faculty of Tourism and Hotel Management, October 6 University, Egypt
}

\begin{abstract}
All organizations of different types and multiple objectives as being open organizations that interact with the market surrounding it especially the kind of market or those relevant market variables and all these organizations are subject to their determinants, so we find that these organizations represented in its administrations are working hard in various ways and means to get to know the market and find the fact and follow the movement of its variables and studying them for the purpose of responding to those variables. However, we find that the degree and level of response will vary from one organization to another depending on several factors, including internal factors regarding the organization, the external factors represented in the market components with its two main public and private type.
\end{abstract}

Keywords: Ministry of Tourism, promotional campaigns, market, variables.

\section{Introduction}

\section{The problem of the study:}

The problem of the study is that the offices of the Ministry of Tourism abroad do not have a comprehensive and strategic perception about the impact of market factors on the activity of these offices and in the degree and level of that impact, especially with regard to the marketing activity by focusing on one of the elements of the marketing mix. Hence, we mean the activity of (promotion) represented in what is carried out by offices of directed and planned promotional campaigns.

Hence, the problem of the study emerges by the observation of heightened and intensification of competition in an environment of rapid change, and continuous evolution in these offices as a pursuit to provide the best promotional campaign; and moreover describe to analyze and determine the degree of response by placing appropriate plans to face the impact of these variables.

\section{The importance of the study:}

The importance of this study lies in that it deals with the logical analysis and description of the main challenges facing the Egyptian tourism. This is done through defining and testing the subject matter of the study (market factors and strategic planning) and in illustrating the impact of both internal and external market with its different elements in marketing performance. (Due to what is represented by marketing activity of paramount importance that can decide how successful external offices of the Ministry of Tourism are are in particular, amid a competitive environment that requires these offices to activate their administrative practices in the fields of planning in order to achieve better marketing performance).

Hence, it is necessary to raise the awareness of these offices to recognize of the importance of market factors and variables and the active response to them by absorbing the impact of these market factors and variables and responding to them and working on drafting and building strategies regarding this side.

\section{Objective of the study}

This study aims to test the impact and effectiveness of both internal and external markets in marketing performance by identifying obstacles and constraints of promotional campaigns as it is one of the important elements of the marketing mix as well as identifying ways and techniques used in the promotion (traditional and contemporary methods and techniques).

In evaluating the role of the office of the level of competition in ways that help these offices in the development of appropriate budgets and strategic plans and in demonstrating the ability of selected offices (the study population) in controlling the market factors and variables in existing and new markets through investment and activation of planned promotional campaigns and in the use of modern technologies to increase the efficiency of design methods of promotional methods and their implementation.

Accordingly, the objective of the study is limited to:

- Diagnosis of market variables that affect (positively or negatively) in the overall marketing performance of offices (the study population) in terms of (Level, Speed, inclusiveness).

- Determining the nature and the response of such offices to market changes. 
- Providing a scientific and realistic perception of what should be done by these offices through the rapid and conscious response to this change in the tourist market in particular and identifying its trends.

\section{Study Hypotheses:}

This study relies on the following Hypotheses:

- The first hypothesis: (there is a significant (statistical) correlation between market variables and the process of planning for promotional campaigns)

- The second hypothesis: (poor efficiency of human resources and its non-specialization adversely affect the planning for promotional campaigns)

\section{Methodology:}

This study relies on the theoretical side using multiple scientific sources relating the subject of the market, and its variables and its impact on the subject of the marketing mix by focusing on promotional mix as it represents one of the main variables of the study. The study uses the logical method and objective linking of ideas in sequence and in the extraction of deduction theoretical results.

The study relied on testing the hypotheses of the inductive analytical approach by examining correlations and influence through the collection of data related to each of the theoretical and field aspects.

\section{Description of study population and sample}

The study population consists of (25) items and a number of interviews with the directors and deputies, as well as current and former officials of the Ministry of Tourism offices abroad. This is conducted to identify the key obstacles and constraints for promotional campaigns.

The collection of data is mainly based on questionnaires - which are carried out in August and September from the year 2014. (25) Questionnaire forms are distributed, of which (23) forms are returned and the overall percentage is $(92 \%)$

\section{Review of Literature}

\section{Components of general market variables}

\section{Economic Variables}

These variables influence mainly the activities of organizations of different types, as the current and future economic conditions affect the work and the performance of organizations and these conditions include a large number of variables such as inflationary trends and the pace of economic activity, interest rates and the ability or availability of raw materials and other tourist supplies as well as fiscal and monetary policy of the state which relates to managing budget Surpluses or Budget Deficits of the State (1)

In addition, to the tax policy of the state, which directly affect the investment spending for offices in a number of areas because the lower tax burden leads to the achievement of higher net income and better potential to the detention of larger amounts of re-investment. thus, the expectations of the Organization on the growth rate of the national economy and the indicators of national income and gross national product affect its plans for expansion in the future.(2)

\section{Political (government) variables}

The public policy of the state and its decrees, its plans and beliefs and philosophy underpinning it at the level of theory and application represent a set of key variables that affect the work of organizations, although this effect varies from one country to another where we see that most of the governments in most countries intervene directly or indirectly in the organization of life if society and economic life as the state is representing political, legal, regulatory and supervisory market since administrative practices for the external offices of the Ministry of Tourism and individuals become a reflection of this market, which affects the organizations and their objectives and flexibility of their movement and opportunities that are allowed to be exploited by them, according to legislation, regulations and instructions in force to which these organizations are subject.(3)

There censorship on their products and their prices and on their finances and the effects of their activities and their market operations.

\section{Social Variables}

The social structure and the relationships prevailing and the system of values, customs and traditions affects largely in the nature of the behavior of organizations and individuals alike. The organizational structures are 
generally also affected by social variables and impacts, as the developing societies are generally characterized by the rule of personal relationships and these variables, would limit the impact of formal procedures and its objectivity in the testing process, recruitment and functional development for the impact of personal factors as well as efficiency of performance standards.(4)

As for the advanced societies, some of them, especially the Japanese society could invest family cohesion objectively to develop organizations and improve the efficiency of their performance, in which the value system is a basis for the authority, unlike Western societies, where we find that the rule of the laws and regulations are driving the work of organizations where the state is responsible for setting controls of public order and the nature of the laws and regulations established by the State are characterized by so high degree of interdependence and complexity that they require organizations to find administrative structures and divisions able to respond to each of these variables.(5)

\section{Technological Variables}

Technology represents a set of regulations and physical and intellectual methods used in the conversion of input to output and it includes science and art in the production and distribution of goods and services. Moreover, it represents a set of concepts and experiences and tools that organizations can through which adapt the external market and controlling it and it means the systematic application of the proceeds of scientific and material knowledge, and it is a civilized and social phenomenon that contribute effectively in cementing the permanent and developed advancement in the framework of the movement of organizations and across their various activities and many of the scientific studies and research have proven that technology that greatly affect the structure of the organization and ways to achieving their goals and investment of technological development results plays a prominent role in determining organizational behavior in general and in achieving the objectives by the organization in addition to that the ability of individuals is affected by the pattern of response according to technological development requirements(6).

\section{Private market components (variables)}

\section{Customers}

They are other individuals that receive the outputs of the organization of goods and services in exchange for other things (money) submitted to them and exchange can occur either directly between the organization and the customers or through other intermediary organizations.(7)

\section{Competitors}

They are organizations that provide goods and services similar to what is provided by the organization and competition occurs in other areas of the organization's work, such as its competition with others to obtain inputs and new competitors can enter in the sector or activity in which Organization operates or competitive Products appear which affects in sales and profits.(8)

\section{Suppliers}

The organization receives its resources from suppliers or processors as they provide it with work and funding and raw materials, information and equipment for the purpose of survival of the organization and they also influence in the organization through the quality of input they provide and their prices and regularity of its supply(9).

\section{Regulatory authorities}

They are the groups and government agencies of direct relevance to the work of the organization and the safety of nearby residents, which make it under the control of the governmental body responsible for that and the organization is also subject to the supervision of the competent government agencies related to the work and prices.(10)

\section{Human Resources}

Individuals working in the organization are composing human resources and different organizations require different types of abilities and skills of the individuals. Thus, the organization that uses is high level of technology require individuals with certain level of skills, unlike small organizations that do not use this kind of technology (11)

\section{Methods of market classification}

The views and opinions of researchers were varied about methods of market classification in standards that are adopted in this category and despite this disparity in the views of researchers, there is a group of foundations 
that most of the researchers agreed upon in the process of classification and of the most important methods that have been used in classification of market were as follows: (12)

\section{External market and the internal market}

the market according to this classification is divided into two main types; namely the internal market that is related to the organization itself in terms of administrative, and technical frameworks operating in it the formal and informal systems and organizational structures and procedures and contexts of its implementation and the technology used and the prevailing communication patterns and the other aspects related to the internal systems of the organization (13)

As for the external market, it includes all the variables that fall outside the framework of the organization itself, which cannot influence significantly and directly, such as the political, and the economic, social systems and other external variables that represent the external products that influence in the path of the organization's work (14)

\section{Public market and private market}

The concept of the public market includes regional (geographical) space or context in which the concerned organization operates with all its political, economic, social, technological variables, and it is a key determinant of the movement of the organization in the implementation of its plans and ways of performing its work and achieving their goals and the impact of these variables shall be indirect and organizations share the existence of general environment.(15)

As for the private market, it include variables most closest connected to it and heaviest interaction with it and has relationship with them in the field of interaction with the community, such as customers, competitors and suppliers and others, and it is often difficult to draw clear lines between the public and private environments Due to the complexity of the relationships and the difficulty of separation of the variables related to each of them and its continued movement (16).

\section{Stable market and unstable (moveable) market}

Stability is a relative matter and depends on this factor sometimes is a basis for the classification of the market, since there are environments that are relatively stable, as is the case for social variables and values rooted in the community and that change very slowly, as well as the case for organizational climate prevailing in the context of community relations, which are often characterized by relatively stability.(17)

As for the unstable or moving market, it is characterized by continuous change and continuous movement of its components and variables and they are subject to rapid change, as is the case for prices, competition and entering new markets, technological developments, and other variables, thus they are all characterized by constant change.

\section{Promotion Strategies}

The promotion one of four key elements that make up the Marketing Mix (Product Strategy, Price Strategy distribution Strategy, Promotion Strategy) and the main objective is summarized in the exercise of promotional activity for goods and services at the level of planning and implementation in the definition of goods and services that have been produced for customers and defining them with their characteristics and advantages and trying to convince them to acquire and use them.

This kind of strategies represents the organization's efforts in order to bring about a certain effect on the behavior of the final consumer or industrial buyer that has harmony with the marketing objectives of the organization, both in terms of increasing sales volume or by attracting new consumers or buyers, or in terms of reducing the demand for a particular product and turning it into another product (18).

\section{Promotion Concept}

There are several definitions for the promotion, including- :

As it is (the process of contacting with others and introducing the types of products held by the seller to them) (19)

The promotion has been defined as (a special mix of advertising tools, personal selling, public relations, sales promotion used by the organization in order to pursue their goals and marketing advertising) (20)

As for (21), he opines that the promotion consists of planning, implementation, control and seeks to coordinate all the efforts of the organization related to the implementation of the purposes of communication with all that that exists in the organization's environment for building information channels and desirable levels of persuasion for the purpose of selling the product). 
Moreover, promotion plays an important role in the field of communications for the definition of the organization and enhancing its relationship with the target audience and influencing this purchasing behavior and guiding it in consistent with the marketing objectives of the organization and creating positive impression for the and the contemporary organizations are managing a large and a complex network of system of promotion that remains the same aspect of marketing and developing necessary plans thereto.

The main idea behind the concept of marketing has taken a new turn recently and it switched from (selling what is produced) into (producing what can be sold) and this new shift requires the availability of a high degree of coordination and joint work between the different divisions of the organization and special departments responsible for the production of goods and services and their marketing.

On the other hand, the limited knowledge about the consumer and his ignorance of many of the issues and considerations and being not aware of the formal and technical considerations of goods that had been provided to them, entail these organizations to guide the consumer to his required rights(22).

Moreover, the position of the State represented by the laws and legislations is presented in order to protect the consumer, where we find that there are exaggerated and unjustified excess, especially in tourist countries in many marketing activities, some of which, especially promotion reach to the extent of high exploitation of the consumer, particularly those have low incomes, such as exaggeration in advertising and packaging and other areas that have only interest or benefit of increased expenditures to promote certain goods and services in its wrong places.(23)

Therefore, we find that the interest by universities and scientific institutes has increased recently in different parts of the world to study the problems of the consumer and the subject of consumer behavior and satisfying his needs and implementation of his desires has become one of the important topics addressed by researchers in their research and studies (24).

Promotion Strategy Components: promotion strategy consists of a set of detailed or secondary plans where most of the studies indicate that the most important of the of the Promotion strategy adopted by the organization

- Promotion Mix Plan: This plan shall identify promotional mix that fits the product by testing promotional tools that ensure full achievement of marketing objectives. Thus, the success of this plan depends on some factors linked to the product the degree such as the nature of risk and its degree and factors associated with the market such as market share and the intensity of competition and consumer factors linked to whether the consumer was final or industrial buyer.(25)

- Promotion Costing Plan: this plan is interested in estimating the size of the expenses that should be spent on the different promotional efforts that have used promotional tools including advertising and personal sale, propaganda and promoting sales, thus, it aims to allocate sufficient funds for each promotional task in such a way to achieve the objectives assigned to them(26).

- Publishing Content Plan: This plan focuses on the formulation and determining the content of the ad in order to deliver a promotional message to consumers as the success of this plan requires the removal of all sources of confusion and uncertainty about the advertising message in order to ensure that message arrives with a high degree of efficiency.

- Publishing Instrument Selecting Plan: in this plan is interested in choosing Publishing Instrument to ensure that the transferring the advertising promotional message to buyers and try to convince them to purchase the item and Publishing Instrument Selecting depends on a range of factors, including the financial capacity of the organization.

- Sales Plan: This plan contributes to the achievement of the objectives of the marketing regarding sales volume and profit margin scheme and its success depends on the extent of their compliance with the general marketing objectives and how they relate to the promotional objectives.

- Plan Motivation: This plan is working to Motivate the sales force and its success requires the use of methods of financial and the non-financial Motivation and establish criteria to assess performance and allocate sales areas properly with providing oversight activities and the provision of adequate communication.(27)

\section{Result and Research Finding}

\section{Questionnaire Analysis}

Table shows (1) of Frequency distribution of the responses of respondents about the degree (poor organizational level) of the functions of promotion where table (1) shows the results that have been reached regarding the proportions of Frequencies and the values of the arithmetic mean and standard deviation with 
respect to variables of poor organizational level of the functions of promotion where values of the arithmetic mean of these variables ranged (4.4783) and (4.0) and standard deviation between (1.0388) and (1.0445), respectively, and the results of a standard deviation recorded higher value of (1.0835) and the lowest value of (0.9638) and therefore:

The managers and administrators and supervisors of marketing systems (the study sample), give wide attention to the variables of the organizational level of the functions of promotion, as the value of the arithmetic mean of all paragraphs of these variables increased on the average standard of (3) as well as the substantial convergence between the arithmetic means, and the Table No. (1) Shows the utmost importance that where they had shown as (\%93.3) of respondents assert (in a positive way) that the success and effectiveness of the promotional campaign depends on the level of internal organization to manage the promotion while (\%8.7) of whom assert otherwise while the $(\mathrm{X})$ no respondents are not sure.

the arithmetic mean of the responses to the sample was (4.4783) which is greater than the standard mean and the standard deviation expressed the degree of conformity and homogeneity in the responses reached (.(1.0388)

The results indicate that $(\% 82.6)$ of respondents confirmed that not giving the prime location for promotion job within the organizational structure reduces the importance and effectiveness of planning for promotional activities, while $(\% 8.7)$ of the respondents assert otherwise, while $(\% 8.7)$ of the sample are not sure and the arithmetic mean of the responses was (52.2) and, unlike the standard deviation, such importance reached $(.(0.9638)$

As for the observation of correlation between promotional activities in the ministry directly by the organization to be able to plan and implement promotional campaigns, this has been confirmed by (\%73.9) of respondents, while \%13of respondents confirms otherwise, while (\%13) are not sure, and the arithmetic mean reached (4) The standard deviation reached (1.0445), where the paragraph ranked the lowest importance.

It is noted that organizations pay attention to the obstacles of planning for promotional campaigns because of the lack of specialized organizations to carry out these works as (\%86.96) of respondents assert this interest while $(\% 13.04)$ assert otherwise where the arithmetic mean was (4.0870) and the standard deviation which indicates that the degree of consistency and harmony was (.(1.0835)

Table (1) shows the frequency distribution of the sample responses about the poor organizational level for functions of promotion

\begin{tabular}{|c|c|c|c|c|c|c|c|c|c|c|c|c|}
\hline \multirow{3}{*}{ Indicator } & \multicolumn{10}{|c|}{ Response scale } & \multirow{3}{*}{$\begin{array}{l}\text { Arithmeti } \\
\mathrm{c} \text { mean }\end{array}$} & \multirow{3}{*}{$\begin{array}{l}\text { standard } \\
\text { deviation }\end{array}$} \\
\hline & \multicolumn{2}{|c|}{1} & \multicolumn{2}{|c|}{2} & \multicolumn{2}{|c|}{3} & \multicolumn{2}{|c|}{4} & \multicolumn{2}{|c|}{5} & & \\
\hline & $\mathrm{F}$ & $\%$ & $\mathrm{~F}$ & $\%$ & $\mathrm{~F}$ & $\%$ & $\mathrm{~F}$ & $\%$ & $\mathrm{~F}$ & $\%$ & & \\
\hline $\mathrm{X} 1$ & 1.0 & 4.3 & 1.0 & 4.3 & - & - & 5.0 & 21.9 & 16.0 & 69.6 & 4.4783 & 1.0388 \\
\hline $\mathrm{X} 2$ & - & - & 2.0 & 8.7 & 2.0 & 8.7 & 7.0 & 30.4 & 12.0 & 52.2 & 4.2609 & 0.9638 \\
\hline $\mathrm{X} 3$ & - & - & 3.0 & 13.0 & 3.0 & 13.0 & 8.0 & 34.8 & 9.0 & 39.1 & 4 & 1.0445 \\
\hline $\mathrm{X} 4$ & 1.0 & 4.3 & 2.0 & 8.7 & - & - & 11.0 & 47.8 & 9.0 & 39.1 & 4.089 & 1.0835 \\
\hline
\end{tabular}

Table (2) shows the results that have been reached through frequency ratios and the values of the arithmetic mean and standard deviation with respect to variables of poor efficiency of the existing human resources in promotional activities where values the arithmetic mean of these variables range between (4.6087(f (4.2609), and the keenness of the organizations on the existence of specialized teams in the field of promotion for the tasks of emergency is to be able to planning for promotional campaigns effectively and insufficiency of specialist office staff in the promotional field hampers planning for promotional campaigns and their implementation with a standard deviation between (0.4990) and (0.9638), respectively, and the results of the standard deviation in the table recorded highest value of (0.9638) and least value of $(0.4990)$ and therefore:

The managers and administrators and supervisors of marketing activities (study sample) give wide attention to the variables of poor efficiency of human resources and lack of rehabilitation as the arithmetic mean value increased for each of paragraphs of these variables in the standard mean (3) as well as the great convergence between the values of the arithmetic means.

Table (2) shows the utmost importance made by managers and administrators and supervisors of marketing activities (study sample) where (\%100) (all members of the sample) stress in a positive manner, the need for 
specialized teams in the field of promotion for the emergency tasks to be able to plan for promotional campaigns with a high mean reached (4.6087) and the standard deviation expressed the degree of conformity and homogeneity in the responses reached (.(0.4990)

The results of the table (12) show that $(\% 87)$ of respondents have expressed great interest in that the nonavailability of qualified human cadres is one of the hindrances standing before planning for promotional campaigns while $(\% 4.3)$ of the respondents assert otherwise while $(\% 8.7)$ of the sample is not sure and the arithmetic mean of the responses reached (4.3913) and the standard deviation that reflects that importance reached (.(0.8388)

The results indicate that $(\% 82.8)$ of respondents assert in a positive way the success and effectiveness of promotional campaigns based on the philosophy of senior management and their belief in the necessity of driving creativity and innovation development in promotional activities, while (\%17.4) of the sample is not sure, and the arithmetic mean has reached(4.3478) and the standard deviation reflects that importance those reached $(.(0.7751)$

As for the inadequacy of the specialist office staff in the field of promotional activities as being a hindrance to the planning of promotional campaigns, $(\% 82.6)$ of respondents confirmed that, while $(\% 8.7)$ of the respondents assert otherwise while $(\% 8.7)$ of the sample is not sure.

The arithmetic mean reached (4.2609) and standard deviation reached (0.9638), where this paragraph was ranked lowest of the importance among the variables of the inadequacy of human resources.

Table (2): Frequency distribution of the sample responses about poor efficiency (inadequacy) of human resources

\begin{tabular}{|c|c|c|c|c|c|c|c|c|c|c|c|c|}
\hline \multirow{3}{*}{ Indicator } & \multicolumn{10}{|c|}{ Response scale } & \multirow{3}{*}{$\begin{array}{c}\text { Arithmetic } \\
\text { mean }\end{array}$} & \multirow{3}{*}{$\begin{array}{l}\text { standard } \\
\text { deviation }\end{array}$} \\
\hline & \multicolumn{2}{|c|}{1} & \multicolumn{2}{|r|}{2} & \multicolumn{2}{|c|}{3} & \multicolumn{2}{|c|}{4} & \multicolumn{2}{|c|}{5} & & \\
\hline & $\mathrm{F}$ & $\%$ & $\mathrm{~F}$ & $\%$ & $\mathrm{~F}$ & $\%$ & $\mathrm{~F}$ & $\%$ & $\mathrm{~F}$ & $\%$ & & \\
\hline $\mathrm{X} 5$ & - & - & 1 & 4.300 & 2 & 8.9 & 7 & 30.4 & 13 & 56.5 & 4.3913 & 0.8388 \\
\hline $\mathrm{X} 6$ & - & - & - & - & - & - & 9 & 39.1 & 14 & 60.9 & 4.6087 & 0.4990 \\
\hline $\mathrm{X} 7$ & - & - & - & - & 4 & 17.4 & 7 & 30.4 & 12 & 52.2 & 4.3478 & 0.7751 \\
\hline $\mathrm{X} 8$ & - & - & 2 & 8.7 & 2 & 8.7 & 7 & 30.4 & 12 & 52.2 & 4.2609 & 0.9638 \\
\hline
\end{tabular}

The table shows (3) the results that have been reached through frequency ratios and the values of the arithmetic mean and standard deviation with respect to variables of " the non-use of modern means of technical development.

The arithmetic mean value for these variables ranges between (4.5652) and (4.2173) and standard deviation ranges $(0.7277)$ and $(0.7358)$, respectively.

And the results of the standard deviation in the table have recorded the highest value $(0.7358)$ and the lowest value of $(.(0.7277)$

Accordingly:

The managers and administrators and supervisors of offices (study sample) give wide attention variables of (non-availability of the using the modern technical development in the production and marketing)

As the value of the arithmetic mean increased for all paragraphs of these variables than the standard arithmetic mean (3) as well as the substantial convergence between their arithmetic means and the above table explains that (\%95.7) of respondents assert (in a positive way) that they pay much attention (that not keeping up with the technical means leads to the weakness of promotional campaigns) while (\%4.3) of whom assert otherwise , while there is nobody in the sample not sure, where the arithmetic mean of the responses to the sample was (4.4782) which is greater than standard arithmetic mean and the standard deviation reflects such importance that reached $(0.7304)$ where respondents expressed lowest importance on the paragraph that "the use of the Internet as a means of promotion has a significant impact on the success of promotional campaigns) and the results indicate that (\%82.6) of respondents assert that (in a positive way), while no one from the respondents contend otherwise while that (\%17.4) of respondents were not sure, where the arithmetic mean reached (4.2173) 
which is greater than standard arithmetic mean. The standard deviation reflects that importance that reached $((0.7358)$

Table (3): Frequency distribution of the sample responses about variables of " non-use of modern means of technical development"

\begin{tabular}{|c|c|c|c|c|c|c|c|c|c|c|c|c|}
\hline \multirow{3}{*}{ Indicator } & \multicolumn{10}{|c|}{ Response scale } & \multirow{3}{*}{$\begin{array}{c}\text { Arithmetic } \\
\text { mean }\end{array}$} & \multirow{3}{*}{$\begin{array}{l}\text { standard } \\
\text { deviation }\end{array}$} \\
\hline & \multicolumn{2}{|c|}{1} & \multicolumn{2}{|c|}{2} & \multicolumn{2}{|c|}{3} & \multicolumn{2}{|c|}{4} & \multicolumn{2}{|c|}{5} & & \\
\hline & $\mathrm{F}$ & $\%$ & $\mathrm{~F}$ & $\%$ & $\mathrm{~F}$ & $\%$ & $\mathrm{~F}$ & $\%$ & $\mathrm{~F}$ & $\%$ & & \\
\hline Y1 & - & - & 1 & 4.3 & - & - & 9 & 39.1 & 13 & 56.5 & 4.4782 & 0.7304 \\
\hline Y2 & - & - & - & - & 4 & 17.4 & 10 & 43.5 & 9 & 39.1 & 4.2173 & 0.7358 \\
\hline Y3 & - & - & 1 & 4.3 & - & - & 10 & 43.5 & 12 & 52.2 & 4.4349 & 0.7277 \\
\hline Y4 & - & - & 1 & 4.3 & - & - & 7 & 30.4 & 15 & 65.2 & 4.5652 & 0.7277 \\
\hline
\end{tabular}

Table (4) shows the results that have been reached through frequency ratios and the values of the arithmetic mean and standard deviation with respect to variables (lack of knowledge of patterns of customers and how to deal with them)

The arithmetic mean value for these variables ranges between (4.7826) and (4.5217) and standard deviation ranges $(0.4217),(45808)$, respectively.

And the results of the standard deviation in the table has recorded the highest value of (458 08) and the lowest value of $(.(0.4217)$

\section{Accordingly:}

The managers and administrators and supervisors of offices (study sample) give wide attention variables (lack of knowledge of customer patterns and how to deal with them)

As the value of the arithmetic mean increased for all paragraphs of these variables than the standard arithmetic mean (3) as well as the substantial convergence between their arithmetic means and the results indicate that the $(\% 100)$ of respondents assert paramount importance of (Knowing the desires and needs of the customers is one of the most important information for planning for promotional campaigns) and the standard deviation reflects that importance that reached (.(0.4217)

And (\%87) of the sample (in a positive way) see that (Knowing complaints of travel agents and trying to find solutions for them is one of the basic steps for the success of promotional activities) as they have shown minimal interest, while $(\% 4.3)$ of the respondents assert otherwise, while $(\% 8.7)$ of the sample not sure, the standard deviation reflects such importance that reached $(.(0.8458)$

Table (4): Frequency distribution of the sample responses about variables "not knowing the customer patterns and how to deal with them) $\mathrm{N}=23$

\begin{tabular}{|c|c|c|c|c|c|c|c|c|c|c|c|c|}
\hline \multirow{3}{*}{ Indicator } & \multicolumn{10}{|c|}{ Response scale } & \multirow{3}{*}{$\begin{array}{c}\text { Arithmetic } \\
\text { mean }\end{array}$} & \multirow{3}{*}{$\begin{array}{r}\text { standard } \\
\text { deviation }\end{array}$} \\
\hline & \multicolumn{2}{|c|}{1} & \multicolumn{2}{|c|}{2} & \multicolumn{2}{|c|}{3} & \multicolumn{2}{|c|}{4} & \multicolumn{2}{|c|}{5} & & \\
\hline & $\mathrm{F}$ & $\%$ & $\mathrm{~F}$ & $\%$ & $\mathrm{~F}$ & $\%$ & $\mathrm{~F}$ & $\%$ & $\mathrm{~F}$ & $\%$ & & \\
\hline Y5 & - & - & - & - & - & - & 5 & 21.6 & 18 & 78.3 & 4.7826 & 0.4217 \\
\hline Y6 & - & - & - & - & - & - & 5 & 21.6 & 18 & 78.3 & 4.7826 & 0.4217 \\
\hline Y7 & - & - & 1 & 4.3 & - & - & 6 & 26.1 & 16 & 69.6 & 4.6086 & 0.7223 \\
\hline Y8 & - & - & 1 & 4.3 & 2 & 9 & 4 & 17.4 & 16 & 69.6 & 4.5217 & 0.8458 \\
\hline
\end{tabular}




\section{Conclusion}

- The results of correlation analysis the presence shows strong and statistically significant correlation between market variables and planning for promotional campaigns.

- The results showed that all impediments and obstacles faced by planning for promotional campaigns are represented in the lack of studying market and its variables and the following-up this change

- The planned and directed marketing strategy including promotional strategy is one of the main reasons for the success of promotional campaigns.

\section{Recommendation}

- Deepening the awareness of office management in general regarding the importance of the subject of the market and the possibility of studying it and following-up to the change that occurs and trying to respond to those changes and responds to them through bringing about internal and structural changes that consistent with changes in the external market.

- The need to develop a clear-cut strategic vision and-and effective flexible strategy to ensure keeping up with the market change and determine its exact response requirements.

- Establishing a section or department within the organizational structure of these offices to study and investigate the market and follow-up its variables, and provide the information necessary in the formulation of strategic plans in the field of marketing activity and various other activities.

- the need that these offices shall give up traditional work patterns and adopting modern methods and patterns in the practice of marketing and promotional activities through the use of the latest technology and means of communication in this area.

- Working to develop long-term plans for training and giving workers in the marketing activities the necessary skills and expertise and the adoption of specific systems to assess the effectiveness of these programs and training plans and following-up their results.

- The tourist offices are required to bring about continuing internal changes (structural and organizational) through absorbing the market variables and creating some kind of balance and adapting with the external market.

\section{References}

1. Obidat, Mohamed Ibrahim,(2003), marketing strategy, behavioral approach, 4th edition, Future House for Publication and Distribution, Amman, Jordan

2. Armstrong, J. \& Kotler, P. (2000), "marketing; An introduction", 5th ed, Prentice Hall, new Jersey.

3. Idris, Thabet Abdel-Rahman, and Al Morsi, Jamal al-Din Mohammed, (2001), contemporary marketing issue 1, University House, Alexandria, Egypt.

4. Daft, Richard, 1. (2001), "Organization Theory and Design", south - western, Thomson leaming, Australia.

5. Aldeuggi, Abu Said,(2001), Marketing Management, 2nd edition, House of bookshop for, printing and publishing, the University of Mosul.

6. Al Salmi, Alaa Abdel-Razzaq,(2000), information technology, 2nd edition, Department of Curriculum for Publishing and Distribution, Amman, Jordan.

7. Gravens, D., (2000) "strategic Marketing" 6th ed, Lrwin Mc Graw - Hill, VSA.

8. Alkeriony, Mohammad Qasim,(2000), the principles of modern marketing, $1^{\text {st }}$ edition, Dar Wael for printing and publishing, Amman, Jordan.

9. Abu Fara, Yusuf Ahmed,(2001), marketing Audit, $3^{\text {rd }}$ edition, Al Khalil University, Oman .0

10. AlBakri, Thamer Yasser,(2002), internet marketing, contemporary approach to deal with the markets, Journal of Economic and Management Sciences, Volume 9, Issue (29).

11. Nigm, Nigm Abboud,(2001), operation management, modern systems, methods and trends, the second part, the Institute of Public Administration, Saudi Arabia, Riyadh .

12. Al Sumaidaie, Mahmoud Jassim,(2004), marketing strategies, quantitative and analytical approach , 2nd edition, Administration of Hamed -Amman Library, Jordan.

13. Wrigt. L., (1995). "Strategic Management Concepts", Prentice- Hall Co. USA.

14. Al Nouri, Qais,(2004), administrative behavior and its social background, 3rd edition , Hamada Foundation for Studies and academic Services, Al Kanady House of publication and distribution, Irbid, Jordan.

15. William, P., jeram, c. , (1999), "Basic marketing", Aclobal Management Approach, Prentice - Hall, New jersey.

16. Gravens, David, w.,(2003), "Strategic Marketing" 6th ed. Lrwin McGraw-Hill. USA. .

17. Jain, S.C,(2001), "Marketing Planning \& Strategy". By south-western, college publishing Cincinnati, Ohia.

18. Darymple, D. \& Parson, L.,(2003), "Marketing Management, text and cases", 7th ed. John publishing.

19. Etzel, M., \& William, S.,(2005), "Marketing", 12th ed. McGraw-Hill lrwin, USA. 
20. Becherer , R.halstead,D. and Haynes , P. (2003) "marketing orientation in smes : effects of the internet environment " new englad journal of entrepreneurship, fairfield. Vol $61: 13-22$

21. Borjesson, s. and Dahlston, f. (2004), "management action in developing .market orientation: a report from a customer knowledge project at Volvo cars ", journal of change management, London , vol , 4: 141-154.

22. Darroch , j , and McNaughtonm R.(2003). " Beyond market orientation : knowledge management and the innovativeness of new zeland firms ", European journal of marketing Bradford vol 37.

23. Godkin Lynn Sean valentine,Gordon Mosely,and Lawrence Silver (2002). "Marketing Orientation and Organizational Learning in Mexican Small Business:The Role of Consulting Support ", International Jornal Of Management . March 2002, Vol.19.

24. kotler, P. (2001). Marketing management : analysis, planning, implementation and control, 11th ed. Englewood, nj : prentice-hall .

25. Kotler, philip, g. Armstrong , j.saunders, and v. wong (2001). Principles of marketing . prentice hall, London

26. Lado, nora, and albert maydeu-olicares (2001). " exploring the link between market orientation and innovation in the European and us insurance markets " international marketing review, London, vol. 18

27. Matte, lisa (2002). "Business at leading small hotel returns slowly ", hotel and motel management, vol 217.

\section{Questions of the questionnaire:}

The impact of the organizational level of the ministry's offices abroad on planning for the promotional campaigns

\begin{tabular}{|c|c|c|c|c|c|c|}
\hline $\begin{array}{c}\text { Serial } \\
\text { no. }\end{array}$ & paragraph & $\begin{array}{l}\text { agreed } \\
\text { strongly }\end{array}$ & agreed & neutral & disagree & $\begin{array}{l}\text { disagree } \\
\text { strongly }\end{array}$ \\
\hline 1 & $\begin{array}{l}\text { The success of the management of promotional } \\
\text { campaigns depends on the level of the internal } \\
\text { organization of the Office }\end{array}$ & & & & & \\
\hline 2 & $\begin{array}{l}\text { The observation by the office of the direct } \\
\text { correlation of the ministry's promotional } \\
\text { activities enables the planning and } \\
\text { implementation of promotional campaigns }\end{array}$ & & & & & \\
\hline 3 & $\begin{array}{l}\text { Lack of specialized divisions promotional } \\
\text { activities within the office represents one of the } \\
\text { obstacles planning for promotional campaigns }\end{array}$ & & & & & \\
\hline
\end{tabular}

\section{Deficiency of existing human resources of promotional activities}

\begin{tabular}{|c|c|c|c|c|c|c|}
\hline $\begin{array}{c}\text { Serial } \\
\text { no. }\end{array}$ & paragraph & $\begin{array}{l}\text { agreed } \\
\text { strongly }\end{array}$ & agreed & neutral & disagree & $\begin{array}{l}\text { disagree } \\
\text { strongly }\end{array}$ \\
\hline 1 & $\begin{array}{l}\text { The need for specialized teams in the field of } \\
\text { promotion affiliated to the ministry to carry out } \\
\text { the emergency tasks }\end{array}$ & & & & & \\
\hline 2 & $\begin{array}{l}\text { lack of qualified human resources is an obstacle } \\
\text { to the success of promotional campaigns }\end{array}$ & & & & & \\
\hline 3 & $\begin{array}{l}\text { success and effectiveness of promotional } \\
\text { campaigns depend on the philosophy of ministry } \\
\text { and its orientations in the field of human } \\
\text { resources }\end{array}$ & & & & & \\
\hline 4 & $\begin{array}{l}\text { Insufficiency of specialized officers in the field } \\
\text { of promotion hinders the success of promotional } \\
\text { activities }\end{array}$ & & & & & \\
\hline
\end{tabular}




\section{The use of modern technical development}

\begin{tabular}{|c|c|c|c|c|c|c|}
\hline $\begin{array}{c}\text { Serial } \\
\text { no. }\end{array}$ & paragraph & $\begin{array}{c}\text { agreed } \\
\text { strongly }\end{array}$ & agreed & neutral & disagree & $\begin{array}{l}\text { disagree } \\
\text { strongly }\end{array}$ \\
\hline 1 & $\begin{array}{l}\text { The lack of keeping up with the } \\
\text { developments in modern technical means } \\
\text { weakens the promotional activities of the } \\
\text { Office }\end{array}$ & & & & & \\
\hline 2 & $\begin{array}{l}\text { Use of the worldwide web (Internet) as a } \\
\text { promotional means has a significant impact } \\
\text { on the success of promotional campaigns }\end{array}$ & & & & & \\
\hline
\end{tabular}

\section{Knowledge of patterns of customers and how to deal with them}

\begin{tabular}{|c|c|c|c|c|c|c|}
\hline $\begin{array}{c}\text { Serial } \\
\text { no. }\end{array}$ & paragraph & $\begin{array}{c}\text { agreed } \\
\text { strongly }\end{array}$ & agreed & neutral & disagree & $\begin{array}{l}\text { disagree } \\
\text { strongly }\end{array}$ \\
\hline 1 & $\begin{array}{l}\text { knowledge of the desires and needs of the } \\
\text { customers is one of the most important } \\
\text { information needed for planning for } \\
\text { promotional campaigns }\end{array}$ & & & & & \\
\hline 2 & $\begin{array}{l}\text { identifying the complaints travel agents and } \\
\text { trying to find solutions to them leads to the } \\
\text { success of promotional campaigns }\end{array}$ & & & & & \\
\hline
\end{tabular}

\section{دراسة أثر العوامل السوقية في تخطيط الحملات الترويجية لمكاتب وزارة السياحة بالخارج هانى أحمد علي خطاب}

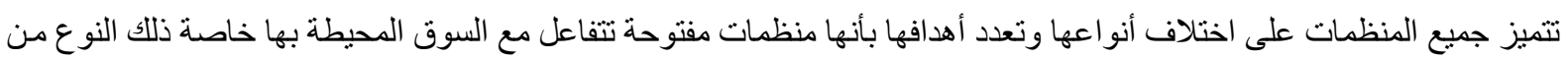

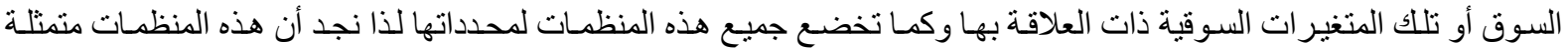

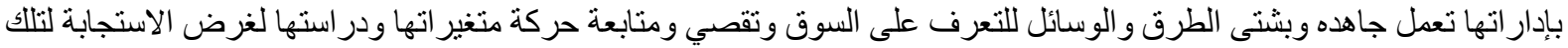

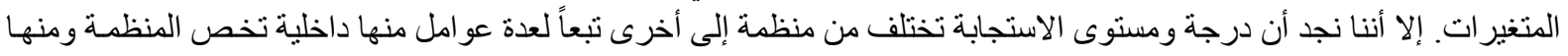

